Egyptian Journal of Aquatic Biology \& Fisheries

Zoology Department, Faculty of Science,

Ain Shams University, Cairo, Egypt.

ISSN $1110-6131$

Vol. 25(4): 917 - 928 (2021)

www.ejabf.journals.ekb.eg

\title{
Effect of Chlorella-based diets on growth of the silver carp, Hypophthalmichthys molitrix
}

\author{
Susan H. Fadda*, and Raky F. Attalla \\ Fish Nutrition Lab. National Institute of Oceanography and Fisheries (NIOF). \\ *Corresponding Author: suzanhassan30@yahoo.com
}

\section{ARTICLE INFO}

Article History:

Received: Aug. 16, 2021

Accepted: Aug. 27, 2021

Online: Aug. 30, 2021

Keywords:

Silver carp,

Feed additives,

Chlorella,

Biochemical parameters.

\section{ABSTRACT}

This study was conducted to investigate the effect of Chlorella vulgaris dried additive on the growth, feed utilization, and biochemical parameters of silver carp fingerlings. The trial was conducted in outdoor concrete rectangular ponds $(4 \mathrm{~m} \times 10 \mathrm{~m} \times 1.5 \mathrm{~m}$, WLD). Fish were reared in duplicate groups of 60 silver carp fingerlings with an average initial body weight and length of $1.7 \pm 0.03 \mathrm{~g}$ and $5.8 \pm 0.6 \mathrm{~cm} /$ fish, respectively, for 16 weeks. Four experimental diets (35\%, protein) were formulated containing 1 , 2, 3, and 4\% of dried Chlorella powder, and a control diet (without additives). Results showed that the growth parameter for experimented fish was significantly $(p<0.05)$ affected by the tested additive. The optimal values of feed conversion and protein efficiency ratios were recorded for the fish-fed diets ( 3 $\& 4)$. Hepato-somatic index (HIS) was significantly $(\mathrm{p}<0.05)$ affected by experimental diets, however, viscera somatic index (VSI) was insignificantly affected ( $>0.05)$. Blood and biochemical parameters were affected by Chlorella inclusion. The present results cleared enhancement of the growth, biological, physiological, and immunity factors of the treated fish by the chlorella additive.

\section{INTRODUCTION}

The Silver carp, Hypophthalmichthys molitrix, is a native species in China and Eastern Siberia, and has been internationally distributed all over the world. It is not only utilized as human food, but also appreciated by its ability to clean water reservoirs from clogging algae (FAO, 2005). Use of feed additives in aquaculture has received a considerable attention in recent years. Microalgae have a broad spectrum of nutritious compounds including proteins, vitamins, essential amino and fatty acids, minerals, and pigments (Becker, 2007). Feeding behavior studies have shown that many fish, including carnivorous fish, ingest algae as a food source. Thus, the use of algae as a feed additive might help in effective utilization of artificial diets in cultured fish (Mustafa \& Nakagawa, 1995). Adding small amounts of micro algae into fish feeds improved growth rate, feed efficiency, body composition and disease resistance (Nakagawa $\boldsymbol{e t}$ al., 1993).

Among microalgae, Chlorella vulgaris is widely distributed in nature, especially in freshwater bodies. Chlorella vulgaris can survive by photo-autotrophy as well as heterotrophy utilizing external carbon source. Hence, Chlorella vulgaris is easily cultured 
in the laboratory and possesses high applied value (Yamaguchi, 1996). It has been proved that Chlorella vulgaris has high content of proteins, lipids, polysaccharides, vitamins, minerals and other nutritional substances, including substances of significant bioactivity (Masojidek et al., 2011). Those substances have high biological and physiological activity, and they are used as feed additives (Xu et al., 2014).

The studies that evaluated hematological and biochemical parameters in carps were conducted on 3 years old carps or more, but there are few studies reported these parameters in fry or fingerling stages, whereas these stages could affect the performance of fish in the future (Nicula et al., 2010; Kopp et al., 2011).

The measurement of total protein, albumin, and globulin in serum or plasma is of considerably diagnostic value in fish as it relates to general nutritional status as well as the integrity of the vascular system and liver functions (Abdel-Tawwab et al., 2008).

This work aimed to study the effect of using dried Chlorella powder as feed additive on growth, and physiological parameters of fingerling stage of Silver carp to produce highquality products for human consumption.

\section{MATERIALS AND METHODS}

\section{Experimental design}

This evaluation was performed with silver carp, Hypophthalmichthys molitrix fingerlings, which were brought from "Saft Khaled" hatchery, El Beheira Governorate. They were held under optimal conditions for two weeks before starting the growth trial. Fish were reared in two outdoor concrete rectangular basins $(4 \times 10 \times 1.5 \mathrm{~m})$. Each basin was divided into five equal parts $(4 \times 2 \times 1.5 \mathrm{~m})$ by nets. Each basin was filled with running water from a nearby irrigation channel, reach from Riah El Menoufy, for one meter deep. The water was changed twice a week. A total of 600 apparently healthy silver carp fingerlings with an average body weight of $1.70 \pm 0.03 \mathrm{~g} / \mathrm{fish}$ were stocked at 60 fingerlings/sector. The growth trial lasted for 16 weeks; $(16 \times 6)$ feeding days. At the start of the experiment, $50 \mathrm{~g}$ fish samples were collected and immediately frozen $\left(-20^{\circ} \mathrm{C}\right)$ and reserved for initial proximate body chemical analysis. Fish were fed twice a day at 10:30, and 14:30 h. The fish were biweekly weighed.

\section{Water quality parameters}

During the experiment, the mean values of water quality parameter $( \pm \mathrm{SD})$ were as follows: water temperature $28.6 \pm 0.3^{\circ} \mathrm{C}$; dissolved oxygen $4.4 \pm 0.4 \mathrm{mg} / \mathrm{L} ; \mathrm{pH} 7.5 \pm 0.2$; total ammonia $0.023 \pm 0.01 \mathrm{mg} / \mathrm{L}$; nitrite $0.025 \pm 0.013 \mathrm{mg} / \mathrm{L}$; and nitrate $0.8 \pm 0.4 \mathrm{mg} / \mathrm{L}$, All water quality parameters were within the acceptable ranges (Abdelhakim $\boldsymbol{e t}$ al., 2002).

\section{Experimental diets}

Dried Chlorella (powder form) was purchased from Biotechnology Lab., National Center of Researches. Five isonitrogenous and isocaloric diets (35\% protein and 416.93 kcal GE/100g diet) were formulated and dried Chlorella powder was included in diets at 
1.0, 2.0, 3.0 and $4.0 \%$ rates besides to the control one. Composition and proximate analysis of the experimental diets are presented in Table (1).

Table 1. Formulation and chemical composition of the experimental diets (\% dry matter bases)

\begin{tabular}{lccccc}
\hline \multirow{2}{*}{ Ingredient (\%) } & \multicolumn{5}{c}{ Experimental diet $^{\mathbf{1}}$} \\
\cline { 2 - 6 } & Control & Diet 1 & Diet 2 & Diet 3 & Diet 4 \\
\hline Fish meal & 30.5 & 30.5 & 30.5 & 30.5 & 30.5 \\
Soybean meal & 31.5 & 31.5 & 31.5 & 31.5 & 31.5 \\
Yellow corn & 25 & 24 & 23 & 22 & 21 \\
Wheat bran & 7 & 7 & 7 & 7 & 7 \\
Dried algae & 0 & 1 & 2 & 3 & 4 \\
NaCl & 2 & 2 & 2 & 2 & 2 \\
Vitamins and minerals & 2 & 2 & 2 & 2 & 2 \\
Fish oil & 1 & 1 & 1 & 1 & 1 \\
Plant oil & 1 & 1 & 1 & 1 & 1 \\
\hline Chemical composition\% & & & & & \\
Dry matter & 88.77 & 88.93 & 89.22 & 89.48 & 88.62 \\
Crude Protein & 35.06 & 35.33 & 35.72 & 36.18 & 36.55 \\
Ether extracts & 6.41 & 6.5 & 6.76 & 6.89 & 7.14 \\
Ash & 14.29 & 13.81 & 13.44 & 12.69 & 13.75 \\
Crude fiber & 7.52 & 7.35 & 7.19 & 7.12 & 6.93 \\
NFE & 36.72 & 37.01 & 36.89 & 37.12 & 35.66 \\
GE ${ }^{4}$ (Kcal/100 g feed) & 409.17 & 412.73 & 416.89 & 421.66 & 424.21 \\
\hline
\end{tabular}

1- Diets 1, 2, 3, and 4 contained 1, 2, 3 and $4 \%$ dried Chlorella vulgaris, respectively.

2- One kg premix contained:

Vitamins:- $48 \times 10^{5} \mathrm{I} . \mathrm{U}$ (A), $6 \times 10^{2} \mathrm{mg}\left(\mathrm{B}_{6}\right), 20 \mathrm{mg}$ (biotin), $8 \times 10^{5}$ I.U. $\left(\mathrm{D}_{3}\right), 144 \mathrm{mg}(\mathrm{E}), 400 \mathrm{mg}\left(\mathrm{B}_{1}\right)$, $1600 \mathrm{mg}\left(\mathrm{B}_{2}\right), 4 \times 10^{3} \mathrm{mg}$ (pantothenic acid), $4 \mathrm{mg}\left(\mathrm{B}_{12}\right), 4 \times 10^{2} \mathrm{mg}$ (niacin), $2 \times 10^{5} \mathrm{mg}$ (choline chloride), and $400 \mathrm{mg}$ (folic acid).

Minerals:- $12 \times 10^{3} \mathrm{mg}$ iron, $16 \times 10^{3} \mathrm{mg}$ manganese, $12 \times 10^{2} \mathrm{mg}$ copper, $120 \mathrm{mg}$ iodine, $80 \mathrm{mg}$ cobalt, 40 $\mathrm{mg}$ Selenium, and $16 \times 10^{3} \mathrm{mg}$ zinc.

3- NFE $=$ Nitrogen free extract $(100-[\mathrm{CP}+\mathrm{Ash}+\mathrm{CF}+\mathrm{EE})]$.

4- GE = Gross energy calculated as 5.64, 9.44, and $4.11 \mathrm{Kcal} /$ gprotein, lipid and carbohydrates, respectively (NRC, 2011).

\section{Fish performance and feed utilization parameters}

The fish were randomly collected twice a week ( 25 fish/treatment) to investigate the growth parameters that were calculated according to Cho and Kaushik (1985) as the following:

Average weight gain $(\mathbf{A W G}, \mathrm{g} /$ fish $)=[$ final body weight $(\mathrm{g})$ - initial body weight $(\mathrm{g})]$;

Average daily gain, (ADG, $\mathrm{g} /$ fish /day) $=[\mathrm{AWG}(\mathrm{g}) /$ Experimental period (days)];

Specific growth rate $($ SGR, \%g/day) $=100$ [Ln final weight - Ln initial weight] /Experimental period (day);

Feed conversion ratio $($ FCR $)=$ feed intake $(\mathrm{g}) /$ body weight gain $(\mathrm{g})$;

Protein efficiency ratio $($ PER $)=$ gain in weight $(\mathrm{g}) /$ protein intake in feed $(\mathrm{g})$;

Protein productive value $(\mathbf{P P V}, \%)=100$ [protein gain in fish $(\mathrm{g}) /$ food protein intake $(\mathrm{g})]$; Energy utilization $(\mathbf{E U}, \%)=100$ [energy gain in fish / energy intake in feed]. 


\section{Biological indices}

After blood samples collection, all the fish samples were scarified and soon the abdominal cavity was opened to remove gut and liver to be weighed at once. The liver and gut (viscera) indices were calculated as follows:

Viscera $($ gut $)$ index $(\mathrm{VI})=($ Viscera weight/fish weight $) \times 100$;

Hepatosomatic index $($ HSI $)=($ Liver weight/fish weight $) \times 100$.

Chemical analysis

Chemical analysis of experimental diets and fish body were conducted to determine the percentages of dry matter (DM \%), crude protein (CP \%), ether extract (EE \%), crude fiber (CF \%), ash \%, and nitrogen free extract (NFE \%) according to the AOAC method (2012).

\section{Haematological parameters}

\section{a. Sampling procedure}

At the end of the experimental period (16 weeks), blood samples (0.5-1 mL blood) were randomly taken ( 5 fish/tank) by puncture of the caudal vein using the heparinized tubes.

\section{b. Blood assays}

The following parameters of blood were tested: the red blood cells (RBC), hemoglobin concentration $(\mathrm{Hb})$, hematocrit value $(\mathrm{Ht})$, mean corpuscular volume (MCV), mean corpuscular hemoglobin $(\mathrm{MCH})$ and mean corpuscular hemoglobin concentration (MCHC) and white blood cells (WBC) count. All determinations were carried out according to Svobodová et al. (1991).

Biochemical determinations of plasma total protein (PTP) and plasma albumin (PA) were determined according to the methods of Armstrong and Carr (1964) and Doumas et al. (1977), respectively. Aspartate aminotransferase (AST) and alanine aminotransferase (ALT) were determined according to Rettman and Frankel (1957), while glucose concentration was measured according to the method of Trainder (1969). Immunoglobulins $\mathrm{G}$ and $\mathrm{M}$ (IgM and $\mathrm{IgG}$ ) were determined according to the method of Feinstein et al. (1985)

\section{Statistical analysis}

The data were subjected to analysis of variance (ANOVA) using general linear models (GLM) procedure; the software used was SPSS (Version 16.0) (SPSS, 1997). Duncan's multiple range tests (Duncan, 1955) was used to compare between means of the control and treated groups, and the model of analysis was as follows:

$\mathbf{Y}_{\mathbf{i j}}=\boldsymbol{\mu}+\mathbf{T}_{\mathbf{i}}+\mathbf{E}_{\mathbf{i j}}$

$\mu=$ the overall mean $_{i}=$ the effect of treatment, and,

$\mathrm{E}_{\mathrm{ij}}=$ the random error

\section{RESULTS AND DISCUSSION}

\section{Growth performance and survival rate of fingerlings}

Growth parameters (average weight gain, average daily gain, and specific growth rate), were significantly increased $(\mathrm{p}<0.05)$ by the increase of dried algae additive in fish diets, compared to the control one (Table 2). 
Best Protein productive value and energy utilization were recorded for those fed D3, where the poorest results were cleared for those fed on D1. Mukherjee et al. (2011) found that protein productive value increased due to the increase of dried algae in fish diets.

The best survival rate, protein efficiency ratio and feed conversion ratio were recorded for those fed diets containing 3\% or $4 \%$ Chlorella additive compared to the control (without Chlorella).

The present investigation is a promising data specially for the fish fed the diet containing 3 or $4 \%$ of Chlorella. The current results may depend on bioactive ingredients (Chlorella vulgaris additive) which promote the growth of fish (Yamaguchi, 1996).

Table 2. Growth and feed utilization of Hypophthalmichthys molitrix fingerlings

\begin{tabular}{|l|c|c|c|c|c|}
\hline \multirow{2}{*}{\multicolumn{1}{|c|}{ Item }} & \multicolumn{5}{c|}{ Experimental diet } \\
\cline { 2 - 6 } & Cont. & D1 & D2 & D3 & D4 \\
\hline Initial body weight & $1.69 \pm 0.010$ & $1.7 \pm 0.005$ & $1.7 \pm 0.010$ & $1.7 \pm 0.001$ & $1.71 \pm 0.015$ \\
\hline Final body weight & $108.88^{\mathrm{b}} \pm 2.68$ & $111.49^{\mathrm{b}} \pm 1.29$ & $114.81^{\mathrm{b}} \pm 2.31$ & $125.16^{\mathrm{a}} \pm 0.54$ & $127.37^{\mathrm{a}} \pm 0.73$ \\
\hline Average weight gain & $107.19^{\mathrm{b}} \pm 2.67$ & $109.79^{\mathrm{b}} \pm 1.30$ & $113.11^{\mathrm{b}} \pm 2.30$ & $123.46^{\mathrm{a}} \pm 0.54$ & $125.67^{\mathrm{a}} \pm 0.72$ \\
\hline Feed consumed & $174.63^{\mathrm{e}} \pm 0.30$ & $177.5^{\mathrm{d}} \pm 0.18$ & $184.24^{\mathrm{c}} \pm 0.55$ & $191.39^{\mathrm{b}} \pm 0.03$ & $194.77^{\mathrm{a}} \pm 0.13$ \\
\hline Feed conversion ratio & $1.63 \pm 0.04$ & $1.62 \pm 0.02$ & $1.63 \pm 0.03$ & $1.55 \pm 0.10$ & $1.55 \pm 0.10$ \\
\hline Average daily gain & $0.96^{\mathrm{b}} \pm 0.022$ & $0.98^{\mathrm{b}} \pm 0.011$ & $1.01^{\mathrm{b}} \pm 0.019$ & $1.10^{\mathrm{a}} \pm 0.010$ & $1.12^{\mathrm{a}} \pm 0.010$ \\
\hline Specific growth rate & $3.47^{\mathrm{c}} \pm 0.156$ & $3.49^{\mathrm{bc}} \pm 0.121$ & $3.51^{\mathrm{b}} \pm 0.118$ & $3.58^{\mathrm{a}} \pm 0.004$ & $3.59^{\mathrm{a}} \pm 0.003$ \\
\hline Protein efficiency ratio & $1.75 \pm 0.04$ & $1.75 \pm 0.03$ & $1.72 \pm 0.04$ & $1.78 \pm 0.01$ & $1.77 \pm 0.01$ \\
\hline Protein productive value\% & $23.71^{\mathrm{c}} \pm 0.16$ & $26.89^{\mathrm{b}} \pm 0.24$ & $28.70^{\mathrm{a}} \pm 0.72$ & $28.24^{\mathrm{a}} \pm 0.06$ & $28.16^{\mathrm{ab}} \pm 0.01$ \\
\hline Energy utilization\% & $16.06^{\mathrm{d}} \pm 0.22$ & $17.79^{\mathrm{c}} \pm 0.47$ & $20.46^{\mathrm{b}} \pm 0.40$ & $20.72^{\mathrm{ab}} \pm 0.11$ & $21.01^{\mathrm{a}} \pm 0.07$ \\
\hline Survival rate \% & $79.15^{\mathrm{c}} \pm 0.85$ & $80.85^{\mathrm{bc}} \pm 0.85$ & $80^{\mathrm{bc}} \pm 0.01$ & $81.7^{\mathrm{ab}} \pm 0.01$ & $83.3^{\mathrm{a}} \pm 0.01$ \\
\hline Initial fish Length & $5.45^{ \pm} \pm 0.05$ & $5.45 \pm 0.05$ & $5.45 \pm 0.05$ & $5.55 \pm 0.05$ & $5.45 \pm 0.05$ \\
\hline Final fish Length & $22.35^{\mathrm{c}} \pm 0.15$ & $22.5^{\mathrm{c}} \pm 0.10$ & $22.7^{\mathrm{bc}} \pm 0.10$ & $23^{\mathrm{b}} \pm 0.01$ & $23.35^{\mathrm{a}} \pm 0.01$ \\
\hline
\end{tabular}

Values are the mean \pm S.E. In the same raw, values with different superscripts are significantly different $(\mathrm{P}<0.05)$.

\section{Biological indices}

Results showed that hepato-somatic index was significantly $(\mathrm{p}<0.05)$ affected by experimental diets compared to the control diet. However, viscera somatic index was insignificantly affected (Table 3).

The highest hepato-somatic index value (2.08) was recorded for those fed D4. Those results were higher than those of Mahboob and Sheri (2002) who mentioned that hepato-somatic index for silver carp was 1.31 when fed on artificial diet for one year.

Additionally, Shi et al. (2016) stated that the HSI value was 5.53 when Crucian carp were fed Chlorella meal. 
Table 3. Biological indices of silver carp fingerlings

\begin{tabular}{|l|c|c|c|c|c|}
\hline \multirow{2}{*}{ Item } & \multicolumn{5}{|c|}{ Experimental diet } \\
\cline { 2 - 6 } & Cont. & D1 & D2 & D3 & D4 \\
\hline Total weight (g) & $100.56^{\mathrm{b}} \pm 4.06$ & $103.46^{\mathrm{b}} \pm 6.81$ & $107.35^{\mathrm{b}} \pm 5.35$ & $118.5^{\mathrm{ab}} \pm 3.87$ & $127.37^{\mathrm{a}} \pm 4.26$ \\
\hline Liver weight $(\mathbf{g})$ & $1.76^{\mathrm{c}} \pm 0.09$ & $1.89^{\mathrm{bc}} \pm 0.09$ & $2.0^{\mathrm{bc}} \pm 0.15$ & $2.43^{\mathrm{ab}} \pm 0.21$ & $2.7^{\mathrm{a}} \pm 0.18$ \\
\hline Viscera weight $(\mathbf{g})$ & $3.3^{\mathrm{b}} \pm 0.11$ & $3.39^{\mathrm{b}} \pm 0.24$ & $3.43^{\mathrm{ab}} \pm 0.11$ & $3.81^{\mathrm{ab}} \pm 0.22$ & $4.12^{\mathrm{a}} \pm 0.25$ \\
\hline Hepato-somtic index & $1.75^{\mathrm{b}} \pm 0.02$ & $1.85^{\mathrm{ab}} \pm 0.08$ & $1.86^{\mathrm{ab}} \pm 0.05$ & $2.04^{\mathrm{a}} \pm 0.10$ & $2.08^{\mathrm{a}} \pm 0.08$ \\
\hline Viscera somatic index & $3.29^{\mathrm{a}} \pm 0.02$ & $3.28^{\mathrm{a}} \pm 0.02$ & $3.21^{\mathrm{a}} \pm 0.07$ & $3.21^{\mathrm{a}} \pm 0.08$ & $3.24^{\mathrm{a}} \pm 0.09$ \\
\hline Total length $(\mathbf{c m})$ & $20.97^{\mathrm{b}} \pm 0.70$ & $22.19^{\mathrm{ab}} \pm 0.72$ & $21.73^{\mathrm{ab}} \pm 0.70$ & $22.92^{\mathrm{ab}} \pm 0.76$ & $24.17^{\mathrm{a}} \pm 0.84$ \\
\hline Body length (cm) & $13.52^{\mathrm{a}} \pm 0.29$ & $13.45^{\mathrm{a}} \pm 0.78$ & $13.42^{\mathrm{a}} \pm 0.39$ & $14.39^{\mathrm{a}} \pm 0.52$ & $15.09^{\mathrm{a}} \pm 0.42$ \\
\hline
\end{tabular}

Values are the mean \pm S.E. In the same raw, values with different superscripts are significantly different $(\mathrm{P}<0.05)$.

\section{Body composition}

Results of fish chemical analysis were significantly $(\mathrm{p}<0.05)$ affected by experimental diets (Table 4). Results of body composition revealed that the lowest protein and highest lipid content were recorded for those fed diet 4 compared to the control. Similarly, Fadda et al. (2017) noticed that when silver carp fries were fed chlorella additive, crude protein and moisture content decreased, and lipids increased accompanied with size increasing. (Ali et al., 2005) stated that an increase in dietary protein led to an increase in fat deposition in the muscle composition of silver carp. Optimum dietary lipid resulted in improved growth rates, feed conversion ratios, nutrient utilization and reduced nitrogen excretion (Yigit et al., 2002; Martins et al., 2007).

These results were explained by Becker (2007) who suggested that cellulosic cell wall of the dried algae (eg. Chlorella) which is indigestible; well reduce the utilization of the micro algae protein. Zeitler et al. (1984) recorded a decreasing trend in water and protein contents of Cyprinus carpio, while fat and energy contents showed a significant increase.

\section{Hematological parameters}

Results of the blood analysis in Table (5) reveal that silver carp fingerlings were significantly $(\mathrm{p}<0.05)$ affected by the four different levels of the Chlorella when compared to the control diet . 
Table 4. Fish carcass composition

\begin{tabular}{|c|c|c|c|c|c|c|}
\hline \multirow{2}{*}{ Item } & \multirow{2}{*}{ Initial } & \multicolumn{5}{|c|}{ Experimental diet } \\
\cline { 3 - 7 } & & Cont. & D1 & D2 & D3 & D4 \\
\hline Moisture \% & $86.25^{\mathrm{a}} \pm 0.05$ & $79.41^{\mathrm{b}} \pm 0.11$ & $76.34^{\mathrm{c}} \pm 0.13$ & $73.54^{\mathrm{e}} \pm 0.06$ & $74.34^{\mathrm{d}} \pm 0.09$ & $74.24^{\mathrm{d}} \pm 0.08$ \\
\hline Protein \% & $52.35^{\mathrm{c}} \pm 1.45$ & $58.42^{\mathrm{a}} \pm 1.19$ & $57.73^{\mathrm{ab}} \pm 0.76$ & $56.3^{\mathrm{ab}} \pm 0.49$ & $55.22^{\mathrm{bc}} \pm 0.24$ & $54.89^{\mathrm{bc}^{\mathrm{c}}} \pm 0.13$ \\
\hline Lipid \% & $5.55^{\mathrm{f}} \pm 0.13$ & $19.7^{\mathrm{d}} \pm 0.28$ & $18.17^{\mathrm{c}} \pm 0.08$ & $21.45^{\mathrm{c}} \pm 0.07$ & $22.44^{\mathrm{b}} \pm 0.17$ & $23.52^{\mathrm{a}} \pm 0.11$ \\
\hline Ash \% & $27.96^{\mathrm{a}} \pm 0.13$ & $16.21^{\mathrm{b}} \pm 0.66$ & $15.86^{\mathrm{bc}} \pm 0.48$ & $14.91^{\mathrm{c}} \pm 0.06$ & $15.36^{\mathrm{bc}} \pm 0.05$ & $12.9^{\mathrm{d}} \pm 0.06$ \\
\hline Rest \% & $14.15^{\mathrm{a}} \pm 1.45$ & $5.69^{\mathrm{c}} \pm 0.26$ & $8.26^{\mathrm{bc}} \pm 1.16$ & $7.35^{\mathrm{bc}} \pm 0.36$ & $6.99^{\mathrm{bc}} \pm 0.36$ & $8.7^{\mathrm{b}} \pm 0.04$ \\
\hline
\end{tabular}

Values are the mean \pm S.E. In the same raw, values with different superscripts are significantly different $(\mathrm{P}<0.05)$.

Table 5. The effect of the dried additive on blood parameters of silver carp

\begin{tabular}{|c|c|c|c|c|c|}
\hline Item & Cont. & D1 & D2 & D3 & D4 \\
\hline $\begin{array}{l}\text { Red blood cells (RBC) } \\
\left(\times 10^{6} \text { cells } / \mathrm{mm}^{3}\right)\end{array}$ & $1.19^{\mathrm{b}} \pm 0.16$ & $1.24^{\mathrm{b}} \pm 0.20$ & $1.31^{\mathrm{b}} \pm 0.03$ & $2.4^{\mathrm{a}} \pm 0.08$ & $2.74^{\mathrm{a}} \pm 0.17$ \\
\hline WBCs $\left(\times 10^{3}\right.$ cells $\left./ \mathrm{mm}^{3}\right)$ & $13.1^{\mathrm{c}} \pm 0.40$ & $13.25^{\mathrm{c}} \pm 0.35$ & $13.15^{\mathrm{c}} \pm 0.25$ & $14.25^{\mathrm{b}} \pm 0.05$ & $16.6^{\mathrm{a}} \pm 0.10$ \\
\hline Hemoglobin $(\mathrm{Hb})(\mathrm{g} / \mathrm{dL})$ & $7.99^{c} \pm 0.05$ & $8.3^{c} \pm 0.20$ & $9.4^{\mathrm{c}} \pm 0.20$ & $13.45^{\mathrm{b}} \pm 0.05$ & $15.85^{\mathrm{a}} \pm 0.85$ \\
\hline Hematocrit $(\mathrm{Ht})(\%)$ & $23.12^{\mathrm{b}} \pm 0.58$ & $23.7^{\mathrm{b}} \pm 0.50$ & $25.5^{\mathrm{b}} \pm 1.40$ & $31.3^{\mathrm{a}} \pm 1$ & $34.95^{\mathrm{a}}=$ \\
\hline $\begin{array}{l}\text { Mean corpuscular volume } \\
(\mathrm{MCV})(\mu \mathrm{m})^{3} \text { or }(\mathrm{FL})\end{array}$ & $95.97^{b} \pm 0.57$ & $98.25^{\mathrm{b}} \pm 0.05$ & $98.75^{\mathrm{b}} \pm 0.45$ & $130.4^{\mathrm{a}} \pm 3.5$ & $135.6^{\mathrm{a}} \pm 0.80$ \\
\hline $\begin{array}{l}\text { Mean corpuscular } \\
\text { hemoglobin }(\mathrm{MCH})(\mathrm{pg})\end{array}$ & $51.63^{\mathrm{b}} \pm 0.68$ & $54.4^{\mathrm{b}} \pm 1.10$ & $57.4^{\mathrm{b}} \pm 0.70$ & $58.55^{\mathrm{b}} \pm 0.15$ & $67.8^{\mathrm{a}} \pm 3.80$ \\
\hline $\begin{array}{l}\text { Mean corpuscular } \\
\text { hemoglobin concentration } \\
(\mathrm{MCHC})(\mathrm{g} / \mathrm{dL})\end{array}$ & $41.73^{c} \pm 1.08$ & $45.8^{\mathrm{bc}} \pm 0.50$ & $48.05^{b c} \pm 2.35$ & $55.9^{\mathrm{b}} \pm 3.80$ & $70.7^{\mathrm{a}} \pm 2.10$ \\
\hline Plats (PLT) $\left(10^{9} / \mathrm{l}\right)$ & $237.5^{\mathrm{c}} \pm 7.50$ & $240.5^{\mathrm{c}} \pm 7.50$ & $324^{\mathrm{b}} \pm 3.00$ & $357^{\mathrm{ab}} \pm 19.00$ & $382.5^{\mathrm{a}} \pm 1.50$ \\
\hline
\end{tabular}

Values are the mean \pm S.E. In the same raw, values with different superscripts are significantly different $(\mathrm{P}<0.05)$.

The results cleared that RBCs count, heamoglobin, hematocrit (\%), $\mathrm{MCV}, \mathrm{MCH}$, and $\mathrm{MCHC}$ increased with additive level increasing. The present findings are referred to as being within the normal range as recorded by Nicula et al. (2010). The oxygen requirements were related to RBCs count in fish (Zanjani et al. 1967), thus, the RBCs increasing may be due to chlorella additive that made a positive effect.

The RBC count is usually used as immune cell parameter to evaluate anemia by feed supplemented with immunostimulant (Morera et al. 2011).

Hemoglobin and hematocrit are essential for fish survival; they are directly related to the ability of blood to bind with oxygen (Bielek \& Strauss, 1993)

The best values of WBCs were $16\left(\mathrm{X} 10^{3}\right.$ cells/ $\left.\mathrm{mm}^{3}\right)$ for the fish fed Diet 4, which contained 4\% Chlorella additive. Khani et al. (2016) recorded that WBCs increased with 
the increasing of Chlorella level in common carp diets. The WBCs are one of the main immune-competent cells of immune system that have efficient role in diseases (Magandottir, 2006).

The increase of WBCs in fish fed different levels of chlorella may be due to Chlorella content from some compounds, such as vitamins and glucans that are available in its cell wall. Consequently, adding Chlorella to diets can enhance the immunity of silver carp.

Serum biochemical parameters were significantly $(\mathrm{p}<0.05)$ affected by experimental diet (Table 6). The present results showed that the total protein ranged from 2.88 to 4.19 $\mathrm{g} / \mathrm{dL}$, while that of Nicula et al. (2010) ranged from 2.1 to 5.7 in cyprinids and was recorded 3.08 in the study of Kamal and Omar (2011) conducted on silver carp.

Moreover, the albumin values were within the normal results $(0.53-2.20 \mathrm{~g} / \mathrm{dL})$ of cyprinids mentioned in the studies of Nicula et al. (2010) and Kamal and Omar (2011).

Table 6. The effect of dried Chlorella vulgaris on biochemical parameters of carp

\begin{tabular}{|l|c|c|c|c|c|}
\hline \multicolumn{1}{|c|}{ Item } & Cont. & D1 & D2 & D3 & D4 \\
\hline $\begin{array}{l}\text { Plasma total protein (PTP) } \\
\text { g/dL }\end{array}$ & $2.82^{\mathrm{c}} \pm 0.04$ & $2.88^{\mathrm{c}} \pm 0.02$ & $3.55^{\mathrm{b}} \pm 0.11$ & $3.87^{\mathrm{b}} \pm 0.06$ & $4.19^{\mathrm{a}} \pm 0.39$ \\
\hline Albumin g/dL & $1.58^{\mathrm{b}} \pm 0.02$ & $1.63^{\mathrm{ab}} \pm 0.01$ & $1.71^{\mathrm{ab}} \pm 0.01$ & $1.76^{\mathrm{ab}} \pm 0.05$ & $1.88^{\mathrm{a}} \pm 0.14$ \\
\hline Globulin g/dL & $1.24^{\mathrm{c}} \pm 0.05$ & $1.25^{\mathrm{c}} \pm 0.01$ & $1.84^{\mathrm{b}} \pm 0.10$ & $2.11^{\mathrm{a}} \pm 0.10$ & $2.31^{\mathrm{a}} \pm 0.25$ \\
\hline Albumin/Globulin ratio & $1.28^{\mathrm{a}} \pm 0.07$ & $1.31^{\mathrm{a}} \pm 0.01$ & $0.93^{\mathrm{b}} \pm 0.05$ & $0.84^{\mathrm{bc}} \pm 0.07$ & $0.82^{\mathrm{c}} \pm 0.03$ \\
\hline $\begin{array}{l}\text { Immunoglobulins M (IgM) } \\
\text { (mg/dL) }\end{array}$ & $14.5^{\mathrm{d}} \pm 0.50$ & $16^{\mathrm{cd}} \pm 1.00$ & $17.5^{\mathrm{c}} \pm 0.50$ & $21.5^{\mathrm{ab}} \pm 2.50$ & $24^{\mathrm{a}} \pm 2.00$ \\
\hline $\begin{array}{l}\text { Immunoglobulins G (IgG) } \\
\text { (mg/dL) }\end{array}$ & $244^{\mathrm{d}} \pm 3.00$ & $256^{\mathrm{c}} \pm 17.50$ & $270^{\mathrm{c}} \pm 14.50$ & $331^{\mathrm{b}} \pm 15.50$ & $354^{\mathrm{a}} \pm 2.50$ \\
\hline Glucose mg/dL & $180.05^{\mathrm{d}} \pm 5.45$ & $181.38^{\mathrm{d}} \pm 6.21$ & $221.09^{\mathrm{c}} \pm 11.44$ & $280.55^{\mathrm{b}} \pm 12.39$ & $307.07^{\mathrm{a}} \pm 6.73$ \\
\hline $\begin{array}{l}\text { Aspartate aminotransferas } \\
\text { (AST) (U/L) }\end{array}$ & $90.16^{\mathrm{e}} \pm 0.46$ & $94.66^{\mathrm{d}} \pm 0.42$ & $108.47^{\mathrm{c}} \pm 19.69$ & $123.14^{\mathrm{b}} \pm 5.89$ & $129.12^{\mathrm{a}} \pm 1.44$ \\
\hline $\begin{array}{l}\text { Alanine aminotransferase } \\
\text { (ALT) (U/L) }\end{array}$ & $61.25^{\mathrm{e}} \pm 5.65$ & $64.06^{\mathrm{d}} \pm 5.11$ & $73.12^{\mathrm{c}} \pm 6.93$ & $89.22^{\mathrm{b}} \pm 2.10$ & $96.96^{\mathrm{a}} \pm 18.56$ \\
\hline
\end{tabular}

Values are the mean \pm S.E. In the same raw, values with different superscripts are significantly different $(\mathrm{P}<0.05)$.

The present results revealed that the IgM in serum were 16, 17.5, 21.5 and 24 (mg/dL) for fish fed on diets 1, 2, 3 and 4, respectively. Those results are confirmed with the findings of Khani et al. (2016) who recorded that, IgM increased with the increasing of Chlorella level in common carp diets.

Zeynab et al. (2013) stated that $\operatorname{IgM}$ was $66.3 \mathrm{mg} / \mathrm{dl}$ for common carp while Krishnaveni et al. (2013) recorded a value of $7.21 \mathrm{mg} / \mathrm{dl}$ for Catla fingerlings. The normal values of the IgM for several fish species ranged between 0.7 and $17 \mathrm{mg} / \mathrm{ml}$ (Israelsson et al., 1991).

The AST and ALT activities in the present study were recorded 94.66-129.12 and 64.06-96.96), respectively, and these values are higher than the reference intervals of cyprinids reported in the study of Nicula et al. (2010).

Blood AST and ALT activities are frequently used in the diagnosis of damaged tissues caused by pollutants on liver, muscles and gills (De la Tore et al., 2000). Therefore, monitoring those enzymes' activities in serum may provide the information related to 
stress caused by algae. It is evidenced that Chlorella additive in fish feeding enhance the growth and survival of fish and does not cause liver disfunctions as evidenced from the enzymatic profiles (Pradhan \& Kumar das, 2015).

\section{CONCLUSION}

The current study concluded that, growth parameters, feed utilization, chemical composition, biochemical conditions and immunity of silver carp fingerlings were affected by adding Chlorella algae.

\section{REFERENCES}

A.O.A.C. (2012): "Official Methods of Analysis of the Association of Official Analytical Chemistry." (A.O.A.C.) International, $19^{\text {th }}$ ed., Gaithersburg, Maryland, USA.

Abdelhakim, N.F.; Baker M.N. and Soltan M.A. (2002). Aquatic Environment for Fish culture. Cairo, (ISBN: 977 - $298-228-5$ ).

Abdel-Tawwab, M.; Abdel-Rahman, A.M. and Ismael, N.E.M. (2008). Evaluation of commercial live bakers' yeast, Saccharomyces cerevisiae as a growth and immunity promoter for fry Nile tilapia, Oreochromis niloticus (L.) challenged in situ with Aeromonas hydrophila. Aquaculture, 280: 185-189.

Ali, M.Z.; Hossain, M. A. and Abdul Mazid, M. (2005). Effect of mixed feeding schedules with varying dietary protein levels on the growth of Sutchi catfish, Pangasius hypophthalmus (Sauvage) with Silver carp, Hypophthalmichthys molitrix (Valenciennes) in ponds. Aquaculture Research, 36: 627- 634.

Armstrong, W.D. and Carr, C.W. (1964). Physiological chemistry laboratory directions. ( $3^{\text {rd }}$ ed.). Burges Publishing Co. Minneapolis, Minnesota.

Becker, E.W. (2007). Microalgae as a source of protein. Biotechnol. Adv., 25(2): 207210.

Bielek, E. and Strauss, B. (1993). Ultrastructure of the granulocytes of the South American lungfish, Lepidosiren paradoxa, morphogenesis and comparison to other leucocystes. Journal of Morphology. 281: 29-41.

Cho, C. Y. and Kaushik, S. J. (1985). Effects of protein intake on net metabiliable and net energy values of fish diets. In: Nutrition and feeding in fish, Academic Press, London, 95- 117.

De la Tore, F.R.; Salibian, A. and Ferrari, L. (2000). Biomarkers assessment in juvenile Cyprinus carpio exposed to waterborne cadmium. Environ. Pollut., 109: 227278. 
Doumas, B.T.; Waston, W. and Biggs, H.H. (1977). Albumine standards and the measurements of serum albumin with Bromocresol Green. Clinical Chemistry Acta 31: 87-96.

Duncan, D.B. (1955). "Multiple range test and multiple F tests" Biometrics, 11 (1): 1-42.

FAO (2005). The dynamics of sanitary and technical requirements: assisting the poor to cope. Expert Consultation, 22-24 June 2004. FAO Animal Production and Health Proceedings No. 4. Rome.

Feinstein, S.; Akov, Y.; Lachmi, B. E.; Lehrer, S.; Rannon, L. and Katz, D. (1985). Determination of human $\operatorname{IgG}$ and $\operatorname{IgM}$ class antibodies to West Nile virus by enzyme linked immunosorbent assay (ELISA). J Med Virol, 17(1): 63-72. doi: 10.1002/ jmv. 1890170110.

Israelsson, O.; Petersson, A.; Bengtén, E.; Wiersma, E.J.; Andersson, J.; Gezelius, G. and Pilström, L. (1991). Immunoglobulin concentration in Atlantic cod, Gadus morhua L., serum and cross-reactivity between anti-cod antibodies and immunoglobulins from other species. Journal of Fish Biology, 39: 265-278.

Kamal, S.M. and Omar W.A. (2011). Effect of Different Stocking Densities on Hematological and Biochemical Parameters of Silver Carp, Hypophthalmichthys molitrix Fingerlings. Life Science Journal, 8(4):580-586.

Khani, M.; Soltani, M.; Shamsaie Mehrjan, M.; Foroudi, F. \& Ghaeni, M. (2016). The effect of Chlorella vulgaris (Chlorophyta, Volvocales) microalga on some hematological and immune system parameters of Koi carp (Cyprinus carpio). Iranian Journal of Ichthyology, 4(1): 62-68.

Kopp, R.; Paliková, M.; Mares, J.; Navrátil, S.; Kubíčk, Z. and Ziková, A.. (2011). Haematological indices are modulated in juvenile carp, Cyprinus carpio L., exposed to microcystins produced by cyanobacterial water bloom. Journal of Fish Diseases, 34: 103114.

Krishnaveni, R.; Palanivelu, K. and Velavan, S. (2013). Effects of probiotics and Spirulina supplementation on haemato-immunological function of Catla catla. International Journal of Research in Fisheries and Aquaculture, 3(4): 176-181

Magnadottir, B. (2006). Innate immunity of fish 67 (overview). Fish and Shelfish Immunology, 20: 137-151.

Mahboob, S. and Sheri, A.N. (2002). Relationships among gonad weight, liver weight and body weight of major, common and some Chinese carps under composite culture system with special reference to pond fertilization. Asian-Aust. J. Anim. Sci. 15(5): 740744. 
Martins, D.A.; Valente, L.M.P. and Lal,1 S.P. (2007). Effects of dietary lipid level on growth and lipid utilization by juvenile Atlantic halibut (Hippoglossus hippoglossus, L.). Aquaculture, 263:150-158.

Masojidek, J.; Kopecky, J.; Gianelli, L. and Torzillo, G. (2011). Productivity correlated to photobiochemical performance of Chlorella mass cultures grown outdoors in thin-layer cascades. Journal of Industrial Microbiology \& Biotechnology, 38: 307 317.

Mukherjee, S.; Parial, D.; Khatoon, N.; Chaudhuri, A.; Senroy, S.; Homechaudhuri, S. and Pal, R. (2011). Effect of Formulated Algal Diet on growth performance of Labeo rohita Hamilton J. Algal Biomass Utln., 2 (4): 1-9.

Mustafa, M. G. and Nakagawa, H. (1995). A review: Dietary benefits of algae as an additive in fish feed. Israeli J. Aquacult. Bamidgeh, 47(3-4): 155-162.

Nakagawa, H.; Nematipour, G. and Yamamoto, M. (1993). Optimum Level of Ulva Meal Diet Supplement to Minimize Weight Loss During Wintering in Black Sea Bream Acanthopagrus schlegeli (Bleeker). Asian Fish Soc., 6:139-48.

Nicula, M.; Bura, M.; Simiz, E.; Banatean-Dunea, I.; Patruica, S.; Marcu, A.; Lunca, M. and Szelei, Z. (2010). Researches concerning reference values assessment of serum biochemical parameters in some fish species from Acipenseridae, Cyprinidae, Esocidae and Salmonidae family. Anim. Sci. Biotech., 43(1): 498-505.

NRC (National Research Council), (2011). Nutrient Requirements of fish and shrimp. The National Academics Press, Washington, DC., 57pp.

Pradhan, J. and Kumar das, B. (2015). Effect of dietary Chlorella vulgaris on liver enzymatic profiles of Rohu Labeo rohita (Hamilton, 1822). Indian J. Fish., 62(2): 132136.

Rettman, S. and Frankel, S. (1957). A colometric determination of glutamic oxaloacetic and glutamic pyruvic transaminase. J. Clin. Pathol. 28(1): 56-63.

Shi, X.; Luo, Z.; Chen, F.; Wei, C.; Wu, K.; Zhu, X. and Liu, X. (2016). Effect of fish meal replacement by Chlorella meal with dietary cellulase addition on growth performance, digestive enzymatic activities, histology and myogenic genes' expression for Crucian carp, Carassius auratus. Aquaculture Research, 48(6): 3244 -3256.

SPSS (1997). Statistical Package for the Social Sciences, Version 16, SSS in Ch, ChiUSA.

Stein, E.A. (1986). Text book of clinical chemistry N. W. Tietz (Ed.) W.B. Saunders Co. Philadelphia, pp. 1818- 1829. 
Svobodová, Z.; Pravda, D. and Paláčková, J. (1991). Unified methods of haematological examination of fish. Research Institute of Fish Culture and Hydrobiology, Vodnany, Edition Methods, No 22: 31 pp.

Trinder, P. (1969). Determination of glucose in blood using glucose oxidase with an alternative oxygen acceptor.Annnual Clin. Biochem. 6: 24-27.

Williamson, E. (2003). Potter's Herbal Cyclopaedia London: C.W. Daniel.

Xu, W.; Gao, Z.; Qi, Z.; Qiu, M.; Peng, J. and Shao, R. (2014). Effect of Dietary Chlorella on the Growth Performance and Physiological Parameters of Gibel carp, Carassius auratus gibelio. Turkish Journal of Fisheries and Aquatic Sciences 14: 53-57.

Yamaguchi, K. (1996). Recent advance in micro-algal bioscience in Japan, with special reference to utilization of biomass and metabolites: a review. Journal of Applied Phycology, 8(6): 487-490. doi: 10.1007/BF02186327.

Yigit, M.; Yardim, Ö. and Koshio, S. (2002). The protein sparing effects of high lipid levels in diets for Rainbow trout (Oncorhynchus mykiss, W. 1792) with special reference to reduction of total nitrogen excretion. Israeli J. Aquaculture, 54(2):79-88.

Zanjani, E.D.; Contrera, J.F.; Gorwn, A.S.; Cooper, G.W.; Wong, K.K. and Katz, R. (1967). The renal erythropoietic factor (REF). III. Enzyme role in erythropoietin production. Proceedings of the Society for Experimental Biology and Medicin 125: 505.

Zeitler, M.H.; Kirchgessner, M. and Schwarz, F.J. (1984). Effects of different proteins and energy supplies on carcass composition of Carp (Cyprinus carpio, L.) Aquaculture, 36: $37-48$.

Zeynab, A.; Khalesi, M. K. and Eskandar, S. K. (2013). Biochemical and hematological profiles of Common Carp (Cyprinus Carpio) under sublethal effects of trivalent chromium. Iranian Journal of Toxicology, 7 (20): 782-792. 